\section{Obs Gyne Review - Journal of Obstetric and Gynecology}

2021 Volume 7 Number 2 March-April

\title{
Assessment of serum adiponectin levels in women with polycystic ovary syndrome
}

\author{
B. Patel M. ${ }^{1}$, C. Patel R. ${ }^{2 *}$ \\ DOI: https://doi.org/10.17511/joog.2021.i02.01
}

\footnotetext{
1 Mukund B. Patel, Resident, Department of Obstetrics \& Gynecology, GMERS Medical College, Dharpur Patan, Gujrat, India.

2* Ramesh C. Patel, Resident, Department of Obstetrics \& Gynecology, GMERS Medical College, Dharpur Patan, Gujrat, India.
}

\begin{abstract}
Background and Aim: Serum adiponectin levels were found to be altered in women with polycystic ovary syndrome (PCOS) due to the increased adiposity commonly observed in them. Accordingly, earlier studies have reported decreased adiponectin levels in PCOS women. the present study was conducted to measure serum adiponectin levels in women with PCOS and to evaluate its association with the biochemical parameters studied. Material and Methods: The present study included 50 women of reproductive age attending the department of Gynecology, tertiary care institute of India and diagnosed with polycystic ovary syndrome based on Rotterdam criteria. Fifty age-matched healthy women were recruited as controls. t. Adiponectin levels were measured along with measurement of fasting blood glucose, lipid profile using commercial kits and insulin resistance (HOMA-IR) was calculated. Results: Both the study groups were matched concerning age, however, PCOS women were obese when compared to healthy women $(p<0.001)$. Serum total cholesterol and triglyceride levels were significantly higher $(p \leq 0.05)$ and serum adiponectin concentration was significantly lower in PCOS women when compared to controls $(p \leq 0.05)$. HDL cholesterol, fasting insulin and HOMA-IR were similar between cases and controls. Adiponectin did not show significant association with any of the parameters studied (Table 2). Conclusion: Serum adiponectin levels are significantly lower in women with polycystic ovary syndrome compared to healthy women. The hyperandrogenemia which is one of the characteristic features of PCOS leads to a state of adiposity which can further cause a decrease in adiponectin levels.
\end{abstract}

Keywords: Cholesterol, Insulin, Polycystic ovary syndrome, Serum adiponectin

Corresponding Author

Ramesh C. Patel, Resident, Department of Obstetrics \& Gynecology, GMERS Medical College, Dharpur Patan, Gujrat, India.

Email: rcpatelshraddha@yahoo.com
How to Cite this Article

To Browse

Patel MB, Patel RC. Assessment of serum adiponectin levels in women with polycystic ovary syndrome. Obs Gyne Review J Obstet Gynecol. 2021;7(2):21-27. Available From

https://obstetrics.medresearch.in/index.php/joog/art icle/view/135

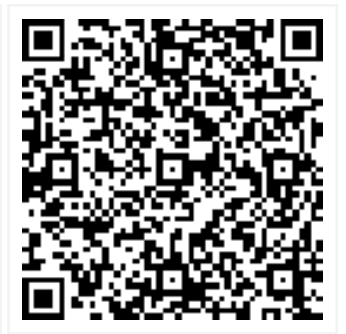

Manuscript Received 2021-04-03

Conflict of Interest No
Review Round 1 2021-04-13

Funding Nil

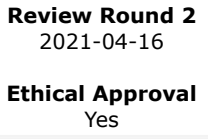

Review Round 3

Accepted 2021-04-30

Plagiarism $\mathbf{X}$-checker $8 \%$

Note Open Access article licensed under a Creative Commons Attribution 4.0 International License https://creativecommons.org/licenses/by/4.0/ unported [CC BY 4.0]. 


\section{Introduction}

Polycystic ovarian syndrome (PCOS) is the most common endocrine disorder affecting reproductiveage women worldwide. [1]. Clinical features of PCOS namely hirsutism, acne, and alopecia originate from high circulating levels of androgens, menstrual irregularities from anovulatory cycles. [2]. and obesity is thought to originate from both the underlying IR and high androgen levels in these patients.[3]. The alarming tribulations associated with the syndrome are past the reproductive axis and these women are at a greater risk of developing the metabolic syndrome at an early age because of IR and obesity observed in $30-60 \%$ of PCOS patients. $[4,7]$. The adipose tissue not only stores a large quantity of fat as an energy source [8]. but also expresses a variety of genes of secretory proteins. $[9,13]$. The human apM1 gene has been recently discovered, and it is exclusively expressed in white adipose tissue. [14]. The product of this gene is called adiponectin, a 244-amino acid protein with high structural homology to collagen VIII, X, complement C1q, and TNF. [15,16]. Adiponectin expression is increased by peroxisome proliferatoractivated receptor agonists. $[17,18]$. Although the physiological role of adiponectin still has to be clarified, recent findings have indicated that it may be a kind of matrix protein with potential antiatherogenic and anti-inflammatory effects. [1922]. Because adiponectin is a fat cell product, secreted into the circulating blood, it might be responsible for the metabolic and neuroendocrine derangements characteristic of obesity and obesityrelated disease, such as PCOS. Serum adiponectin levels were found to be altered in women with PCOS due to the increased adiposity commonly observed in them. Accordingly, earlier studies have reported decreased adiponectin levels in PCOS women. Further, the altered adiponectin levels are proposed to contribute to the endocrine and metabolic disturbances observed in PCOS women. In this background, the present study was conducted to measure serum adiponectin levels in women with PCOS and to evaluate its association with the biochemical parameters studied.

\section{Material and Methods}

The present study included 50 women of reproductive age attending the department of Gynecology, tertiary care institute of India and diagnosed with polycystic ovary syndrome based on Rotterdam criteria.
Fifty age-matched healthy women were recruited as controls. All the participants were included after informed consent.

Patients with type 2 diabetes mellitus, chronic liver disease, thyroid dysfunction, and using medications such as steroids, contraceptives, hypoglycemic/antidiabetic drugs were excluded from the study. Five (5) $\mathrm{mL}$ of fasting venous blood sample was collected from all the subjects after informed consent. Plasma samples were separated immediately and plain samples were allowed to clot and separated by centrifugation at $3000 \mathrm{rpm}$ for 15 min. The separated samples were transferred and stored inappropriately labelled aliquots and stored at $-800 \mathrm{C}$ until further biochemical analysis. The glucose oxidase-peroxidase (GOD-POD) method was used for the measurement of fasting blood sugar, total cholesterol and triglycerides were determined by enzymatic endpoint colourimetric methods and high-density lipoprotein cholesterol was estimated by selective inhibition method. All these parameters were analyzed using commercial kits on Beckman Unicel DXC 600 autoanalyzer. Adiponectin was assayed by enzyme-linked immunosorbent assay (ELISA) on Chemwell awareness technology. Insulin assay was done by chemiluminescence immunoassay (CLIA) on Beckman access 2 analyzer. Insulin resistance was calculated as homeostasis model assessment-estimated insulin resistance (HOMA-IR), using the formula, 10 HOMA- IR= Fasting plasma insulin $(\mathrm{mU} / \mathrm{L}) \times$ Fasting plasma glucose $\mathrm{mmol} / \mathrm{L}) / 22.5$.

Statistical analysis: The recorded data was compiled and entered in a spreadsheet computer program (Microsoft Excel 2007) and then exported to the data editor page of SPSS version 15 (SPSS Inc., Chicago, Illinois, USA). For all tests, confidence level and level of significance were set at $95 \%$ and $5 \%$ respectively.

\section{Results}

Table 1: Demographic characteristics and biochemical parameters studied in healthy controls and women with polycystic ovary syndrome

\begin{tabular}{|l|l|l|l|}
\hline \multicolumn{1}{|c|}{ Variables } & \multicolumn{1}{c|}{ PCos women } & \multicolumn{1}{c|}{ Control } & P-value \\
\hline Age $($ Years $)$ & $20.65 \pm 2.51$ & $20.54 \pm 2.25$ & 0.1 \\
\hline Number of subjects & 50 & 50 & \\
\hline BMI $(\mathrm{kg} / \mathrm{m} 2)$ & $21.87 \pm 2.84$ & $24.92 \pm 4.3$ & $0.001^{*}$ \\
\hline Plasma FBS $(\mathrm{mg} / \mathrm{dL})$ & $96.50 \pm 6.50$ & $95.80 \pm 8.60$ & 0.4 \\
\hline Serum TC $(\mathrm{mg} / \mathrm{dL})$ & $149.87 \pm 18.54$ & $166.90 \pm 27.15$ & $0.02 *$ \\
\hline
\end{tabular}




\begin{tabular}{|l|l|l|l|}
\hline Serum TGL $(\mathrm{mg} / \mathrm{dL})$ & $85.40 \pm 44.20$ & $122.54 \pm 81.70$ & $0.003 *$ \\
\hline Serum HDL-C $(\mathrm{mg} / \mathrm{dL})$ & $65.60 \pm 6.25$ & $66.42 \pm 6.87$ & 0.24 \\
\hline Serum adiponectin $(\mu \mathrm{g} / \mathrm{dL})$ & $7.10 \pm 3.16$ & $4.42 \pm 2.31$ & $0.001^{*}$ \\
\hline Fasting Insulin $(\mu \mathrm{IU} / \mathrm{mL})^{*}$ & $9.06(6.25-12.41)$ & $9.01(6.98-18.14)$ & 0.32 \\
\hline HOMA-IR* & $2.23(1.54-2.80)$ & $2.24(1.81-4.46)$ & 0.28 \\
\hline
\end{tabular}

* indicates statistically significance at $p \leq 0.05$

Table 2: Association of adiponectin with the parameters studied in women with PCOS

\begin{tabular}{|l|l|l|}
\hline \multicolumn{1}{|c|}{ Adiponectin $(\mathbf{n = 5 0})$} & \multicolumn{1}{|c|}{$\mathbf{R}$} & \multicolumn{1}{c|}{ P value } \\
\hline Age & -0.3 & 0.08 \\
\hline BMI & -0.2 & 0.25 \\
\hline FBS & 0.19 & 0.2 \\
\hline TGL & 0.08 & 0.5 \\
\hline HDL-C & -0.01 & 0.8 \\
\hline Insulin & -0.02 & 0.9 \\
\hline
\end{tabular}

* indicates statistical significance at $p \leq 0.05$

$\mathrm{R}=$ correlation coefficient; $\mathrm{BMI}=$ body mass index; FBS=fasting blood sugar; TGL=triglycerides; HDL$\mathrm{C}=$ high density lipoprotein cholesterol; HOMA-IR= homeostasis model assessment-estimated insulin resistance. The demographic characteristics and biochemical parameters studied in healthy controls and PCOS women were shown in Table 1 . Both the study groups were matched concerning age, however, PCOS women were obese when compared to healthy women $(p<0.001)$.

Serum total cholesterol and triglyceride levels were significantly higher $(p \leq 0.05)$ and serum adiponectin concentration was significantly lower in PCOS women when compared to controls $(p \leq 0.05)$. HDL cholesterol, fasting insulin and HOMA-IR were similar between cases and controls. Adiponectin did not show significant association with any of the parameters studied (Table 2).

\section{Discussion}

It has been established that adiponectin is almost exclusively produced in adipose tissue. [23. Adiponectin is probably one of the most important adipocytokines of adipose tissue. [24]. It is highly expressed and actively secreted by adipocytes. [25]. it is abundantly present in human circulation and displays a variety of functions, including antiatherogenic, antiinflammatory, and insulinsensitizing properties. [26,27].

Polycystic ovary syndrome is commonly associated with metabolic disturbances such as glucose intolerance and dyslipidemia in addition to hormonal changes.
Obesity is not only observed in about $50 \%$ of women with PCOS, but is also involved in the development of metabolic complications. The altered adiponectin levels in the setting of increased adiposity in PCOS women are one of the important factors contributing to complications. PCOS women had significantly lower serum adiponectin levels when compared to healthy women [Table 1]. Similar findings were reported in earlier studies. [28,29].

This relationship between PCOS and low adiponectin also changed a little across different age groups. Furthermore, family histories of PCOS and IR were also significantly associated with lower adiponectin levels. We found low levels of adiponectin in lean young women with PCOS. Several studies have demonstrated reduced levels of serum adiponectin in women with PCOS. [30,35]. Also, few of them have shown an association of low adiponectin levels in PCOS women irrespective of the weight and/or BMI of patients. [31-33].

In the present study, PCOS women were overweight and had significantly higher BMI than controls [Table 1]. It was reported that the expression of messenger RNA (mRNA) for adiponectin is significantly lower in women with PCOS compared with weight-matched women without PCOS. This decreased expression of adiponectin mRNA, which was observed in both subcutaneous and visceral fat tissue, was found to be consistent with the lower levels of circulating adiponectin levels that are observed in women with PCOS. [36].

The increased adiposity as indicated by a higher BMI in PCOS women in the present study might be responsible for the lower adiponectin levels observed in them. On the other hand, Li et al. [37]. and Connor et al [38]. who have also observed decreased total adiponectin and HMW adiponectin levels in PCOS women suggested that the lowered adiponectin levels occur independent of BMI and insulin resistance and that the low levels of HMW adiponectin in PCOS are a result of posttranscriptional / translational modifications. [38].

A systematic review and meta-analysis by Toulis et al., on a sub-analysis by using studies only with PCOS cases and controls matched on BMI, revealed that PCOS women had lower levels of adiponectin after controlling for the potential effects of obesity by BMI matching. This suggests that serum adiponectin levels are not independently determined by the degree of adiposity in women but the underlying disease may also have some role. 
A possible explanation for this finding is that lower adiponectin levels in PCOS women might be a result of increasing IR in these patients as supported by our study. [39]. However, the HDL cholesterol levels were similar in PCOS women and controls $(p=0.550)$ [Table 1]. Earlier studies have reported increased total cholesterol and triglycerides and decreased HDL cholesterol in PCOS women, compared to controls.[40]. Dyslipidemia in the setting of polycystic ovary syndrome is multifactorial in origin. The increased prevalence of obesity, insulin resistance and hyperandrogenemia have all been proposed to be involved in the lipoprotein disturbances observed in PCOS women.[41]. Increased lipogenesis, impaired clearance, decreased oxidation of fatty acids and their increased availability and an increased secretion of very-low-density lipoprotein (VLDL) particles by the hepatocytes contribute to the increased triglyceride levels in the presence of insulin resistance. [40]. Adiponectin is actively involved in energy homeostasis through its role in carbohydrate and lipid metabolism and is involved in causing insulin sensitivity. The present study analyzed the association of adiponectin with the studied parameters. It was observed that adiponectin showed a negative but no significant association with age and BMI [Table 2]. These findings are in accord with those of others. [42,43]. who established adiponectin as the only 'adipokine' that is suppressed by increased body fat. The adiponectin levels in PCOS women in the present study showed no significant inverse association with fasting insulin levels and HOMA-IR [Table 2]. Similar findings were reported by Ramanand et al. [44]. Adiponectin thus may serve as a useful marker in detecting cases of PCOS with atypical presentation or in individuals with a family history of PCOS. Longitudinal studies are therefore warranted to understand the initiating point in the development of PCOS in females having a family history of PCOS and IR.

\section{Conclusion}

Serum adiponectin levels are significantly lower in women with polycystic ovary syndrome compared to healthy women. The hyperandrogenemia which is one of the characteristic features of PCOS leads to a state of adiposity which can further cause a decrease in adiponectin levels. The low adiponectin levels further contribute to the metabolic complications associated with PCOS including insulin resistance and dyslipidemia.
The insulin resistance and the resultant hyperinsulinemia in turn lead to ovarian hormonal disturbances, thus forming a vicious cycle. Thus, the altered adiponectin levels in polycystic ovary syndrome appear to form an important link between obesity and the complications of PCOS. Therapeutic interventions using drugs such as metformin and weight reduction programmes are known to improve adiponectin levels and may provide beneficial effects.

\section{Reference}

01. Toulis KA, Goulis DG, Farmakiotis D, Georgopoulos NA, Katsikis I, Tarlatzis BC, et al. Adiponectin levels in women with polycystic ovary syndrome- a systematic review and a metaanalysis. Hum Reprod Update. 2009 MayJun;15(3)297-307. doi: 10.1093/humupd/dmp006 [Crossref][PubMed][Google Scholar]

02. Ferriman D, Gallwey Jd. Clinical assessment of body hair growth in women. J Clin Endocrinol Metab. 1961 Nov;21;1440-7. doi: 10.1210/jcem-21-111440 [Crossref][PubMed][Google Scholar]

03. Shroff R, Syrop CH, Davis W, Van Voorhis BJ, Dokras A. Risk of metabolic complications in the new PCOS phenotypes based on the Rotterdam criteria. Fertil Steril. 2007 Nov;88(5)1389-95. doi: 10.1016/j.fertnstert.2007.01.032

[PubMed][Google Scholar]

04. Cho LW, Randeva HS, Atkin SL. Cardiometabolic aspects of polycystic ovarian syndrome. Vasc Health Risk Manag. 2007;3(1)55-63. [Crossref][PubMed] [Google Scholar]

05. Handelsman Y. Metabolic syndrome pathophysiology and clinical presentation. Toxicol Pathol. 2009 Jan;37(1)18-20. doi: $10.1177 / 0192623308329288$ [Crossref][PubMed] [Google Scholar]

06. Vuguin PM. Interventional studies for polycystic ovarian syndrome in children and adolescents. Ped Health. 2010 Feb;4(1)59-73. doi: 10.2217/phe.09.69 [Crossref][PubMed][Google Scholar]

07. Katulski K, Meczekalski B. Historia naturalna zespołu policystycznych jajników [Natural history of polycyclic ovary syndrome]. Pol Merkur Lekarski. 2010 Jul;29(169)58-60. Polish [Crossref][PubMed] [Google Scholar] 
08. Trayhurn P, Beattie JH. Physiological role of adipose tissue- white adipose tissue as an endocrine and secretory organ. Proc Nutr Soc. 2001;60(3)329-39. doi: 10.1079/pns200194 [Crossref][PubMed][Google Scholar]

09. Maeda K, Okubo K, Shimomura I, Mizuno K, Matsuzawa $Y$, Matsubara K. Analysis of an expression profile of genes in the human adipose tissue. Gene. 1997;190(2)227-35. doi: 10.1016/s0378-11 19(96)00730-5 [Crossref][PubMed][Google Scholar]

10. Koutnikova $H$, Auwerx J. Regulation of adipocyte differentiation. Ann Med. 2001 Nov;33(8)556-61. doi: $10.3109 / 07853890108995966$ [Crossref] [PubMed][Google Scholar]

11. McTernan PG, McTernan CL, Chetty R, Jenner K, Fisher FM, Lauer MN, et al. Increased resistin gene and protein expression in human abdominal adipose tissue. J Clin Endocrinol Metab. 2002;87(5) 2407. doi: 10.1210/jcem.87.5.8627 [Crossref][PubMed] [Google Scholar]

12. Haque WA, Shimomura I, Matsuzawa Y, Garg A. Serum adiponectin and leptin levels in patients with lipodystrophies. J Clin Endocrinol Metab. 2002;87(5) 2395. doi: $10.1210 / j c e m \cdot 87.5 .8624$ [Crossref] [PubMed][Google Scholar]

13. Matsuzawa $Y$, Funahashi $T$, Nakamura $T$. Molecular mechanism of metabolic syndrome $X$ contribution of adipocytokines adipocyte-derived bioactive substances. Ann $N$ Y Acad Sci. 1999;892;146-54. doi: 10.1111/j.1749-6632.1999. tb07793.x[Crossref][PubMed][Google Scholar]

14. Saito K, Tobe T, Minoshima S, Asakawa S, Sumiya J, Yoda M, Nakano Y, Shimizu N, Tomita M. Organization of the gene for gelatin-binding protein (GBP28). Gene. 1999;229(1-2)67-73. doi: 10.1016/ s0378-1119(99)00041-4[Crossref][PubMed][Google Scholar]

15. Halleux CM, Takahashi M, Delporte ML, Detry R, Funahashi T, Matsuzawa Y, Brichard SM. Secretion of adiponectin and regulation of apM1 gene expression in human visceral adipose tissue. Biochem Biophys Res Commun. 2001;288(5)1102-7. doi: 10.1006/bb rc.2001.5904 [Crossref][PubMed][Google Scholar]

16. Takahashi M, Arita Y, Yamagata K, Matsukawa Y, Okutomi K, Horie $M$, et al. Genomic structure and mutations in adipose-specific gene, adiponectin. Int J Obes Relat Metab Disord. 2000 Jul;24(7):861-8. doi: 10.1038/sj.ijo.0801244 [Crossref][PubMed] [Google Scholar]
17. Maeda N, Takahashi M, Funahashi T, Kihara S, Nishizawa $H$, Kishida $K$, et al. PPARgamma ligands increase expression and plasma concentrations of adiponectin, an adipose-derived protein. Diabetes. 2001 Sep;50(9)2094-9. doi: 10.2337/diabetes.50.9.2094 [Crossref][PubMed] [Google Scholar]

18. Yang WS, Jeng $\mathrm{CY}, \mathrm{Wu} \mathrm{TJ}$, Tanaka S, Funahashi T, Matsuzawa Y, Wang JP, Chen CL, Tai TY, Chuang LM. Synthetic peroxisome proliferator-activated receptor-gamma agonist, rosiglitazone, increases plasma levels of adiponectin in type 2 diabetic patients. Diabetes Care. 2002 Feb;25(2)376-80. doi: 10.2337/diacare.25.2.376 [Crossref][PubMed] [Google Scholar]

19. Ouchi N, Kihara S, Arita $Y$, Maeda K, Kuriyama H, Okamoto Y, Hotta K, Nishida M, Takahashi M, Nakamura T, Yamashita S, Funahashi T, Matsuzawa Y. Novel modulator for endothelial adhesion molecules- adipocyte-derived plasma protein adiponectin. Circulation. 1999 Dec 2128;100(25)2473-6. doi: 10.1161/01.cir.100.25.2473 [Crossref][PubMed] [Google Scholar]

20. Matsubara M, Maruoka S, Katayose S. Decreased plasma adiponectin concentrations in women with dyslipidemia. J Clin Endocrinol Metab. 2002 Jun;87(6)2764-9. doi: 10.1210/jcem.87.6.8550 [Crossref][PubMed] [Google Scholar]

21. Arita $Y$, Kihara S, Ouchi N, Maeda K, Kuriyama $\mathrm{H}$, Okamoto $\mathrm{Y}$, et al. Adipocyte-derived plasma protein adiponectin acts as a platelet-derived growth factor-BB-binding protein and regulates growth factor-induced common postreceptor signal in vascular smooth muscle cell. Circulation. 2002 Jun $18 ; 105(24) 2893-8 . \quad d o i$ : 10.1161/01.cir.0000018622.84402.ff [Crossref] [PubMed][Google Scholar]

22. Yang WS, Lee WJ, Funahashi T, Tanaka S, Matsuzawa $\mathrm{Y}$, Chao $\mathrm{CL}$, et al. Weight reduction increases plasma levels of an adipose-derived antiinflammatory protein, adiponectin. J Clin Endocrinol Metab. 2001;86(8)3815-9. doi: 10.1210/jcem. 86.8.7741 [Crossref][PubMed][Google Scholar]

23. Berg AH, Combs TP, Du X, Brownlee M, Scherer $\mathrm{PE}$. The adipocyte-secreted protein Acrp30 enhances hepatic insulin action. Nat Med. 2001 Aug;7(8)94753. doi: 10.1038/90992 [Crossref][PubMed][Google Scholar] 
24. Kondo $H$, Shimomura I, Matsukawa $Y$, Kumada M, Takahashi M, Matsuda M, et al. Association of adiponectin mutation with type 2 diabetes- a candidate gene for the insulin resistance syndrome. Diabetes. 2002 Jul;51(7)2325-8. doi: 10.2337/diabetes.51.7.2325 [Crossref][PubMed] [Google Scholar]

25. Tsao TS, Lodish HF, Fruebis J. ACRP30, a new hormone controlling fat and glucose metabolism. Eur J Pharmacol. 2002 Apr 12;440(2-3)213-21. doi: 10.1016/s0014-2999(02)01430-9

[Crossref] [PubMed][Google Scholar]

26. Ouchi N, Kihara S, Arita Y, Okamoto Y, Maeda K, Kuriyama $\mathrm{H}$, et al. Adiponectin, an adipocytederived plasma protein, inhibits endothelial NFkappaB signaling through a cAMP-dependent pathway. Circulation. 2000 Sep 12;102(11)1296301. doi: 10.1161/01.cir.102.11.1296 [Crossref] [PubMed][Google Scholar]

27. Stefan $N$, Bunt JC, Salbe AD, Funahashi $T$, Matsuzawa Y, Tataranni PA. Plasma adiponectin concentrations in children: relationships with obesity and insulinemia. J Clin Endocrinol Metab. 2002 Oct;87(10)4652-6. doi: 10.1210/jc.2002-020694 [Crossref][PubMed][Google Scholar]

28. Yilmaz M, Bukan N, Demirci H, Oztürk C, Kan E, Ayvaz G, Arslan M. Serum resistin and adiponectin levels in women with polycystic ovary syndrome. Gynecol Endocrinol. 2009 Apr;25(4)246-52. doi: 10.1080/09513590802653833 [Crossref][PubMed] [Google Scholar]

29. Mannerås-Holm L, Leonhardt $H$, Kullberg J, Jennische $E$, Odén A, Holm G, et al. Adipose tissue has aberrant morphology and function in PCOSenlarged adipocytes and low serum adiponectin, but not circulating sex steroids, are strongly associated with insulin resistance. J Clin Endocrinol Metab. 2011 Feb;96(2)E304-11. doi: 10.1210/jc.20101290 [Crossref][PubMed][Google Scholar]

30. Ardawi MS, Rouzi AA. Plasma adiponectin and insulin resistance in women with polycystic ovary syndrome. Fertil Steril. 2005 Jun;83(6)1708-16. doi: 10.1016/j.fertnstert.2004.11.077 [Crossref] [PubMed][Google Scholar]

31. Barber TM, Hazell M, Christodoulides C, Golding SJ, Alvey C, Burling $K$, et al. Serum levels of retinolbinding protein 4 and adiponectin in women with polycystic ovary syndrome- associations with visceral fat but no evidence for fat massindependent effects on pathogenesis in this
Condition. J Clin Endocrinol Metab. 2008 Jul;93(7)2859-65. doi: 10.1210/jc.2007-2759 [Crossref][PubMed][Google Scholar]

32. Carmina E, Orio F, Palomba S, Cascella T, Longo RA, Colao AM, Lombardi G, Lobo RA. Evidence for altered adipocyte function in polycystic ovary syndrome. Eur J Endocrinol. 2005 Mar;152(3)38994. doi: 10.1530/eje.1.01868 [Crossref][PubMed] [Google Scholar]

33. Escobar-Morreale HF, Villuendas G, BotellaCarretero JI, Alvarez-Blasco F, Sanchón R, LuqueRamírez $M$, et al. Adiponectin and resistin in PCOSa clinical, biochemical and molecular genetic study. Hum Reprod. 2006 Sep;21(9)2257-65. doi: 10.1093/humrep/del146 [Crossref][PubMed][Google Scholar]

34. Sepilian V, Nagamani M. Adiponectin levels in women with polycystic ovary syndrome and severe insulin resistance. J Soc Gynecol Investig. 2005 Feb;12(2)129-34. doi: 10.1016/j.jsgi.2004.09.003 [Crossref][PubMed][Google Scholar]

35. Wickham EP 3rd, Cheang KI, Clore JN, Baillargeon JP, Nestler JE. Total and high-molecular weight adiponectin in women with the polycystic ovary syndrome. Metabolism. 2011 Mar;60(3)36672. doi: 10.1016/j.metabol.2010.02.019 [Crossref] [PubMed][Google Scholar]

36. Escobar-Morreale HF, Villuendas G, BotellaCarretero JI, Alvarez-Blasco F, Sanchón R, LuqueRamírez $M$, et al. Adiponectin and resistin in PCOSa clinical, biochemical and molecular genetic study. Hum Reprod. 2006 Sep;21(9)2257-65. doi: 10.1093/humrep/del146 [Crossref][PubMed][Google Scholar]

37. Li H, Chen Y, Li Y, Huang J, Zhao X, Chen X, Yang D. [A case-control study of correlation between serum adiponectin levels and polycystic ovary syndrome]. Zhonghua Fu Chan Ke Za Zhi. 2015 Nov;50(11)814-8. [Crossref][PubMed][Google Scholar]

38. O'Connor A, Phelan N, Tun TK, Boran G, Gibney J, Roche HM. High-molecular-weight adiponectin is selectively reduced in women with polycystic ovary syndrome independent of body mass index and severity of insulin resistance. J Clin Endocrinol Metab. 2010 Mar;95(3)1378-85. doi: 10.1210/jc.2009-1557 [Crossref][PubMed][Google Scholar] 
39. Toulis KA, Goulis DG, Farmakiotis D, Georgopoulos NA, Katsikis I, Tarlatzis BC, Papadimas I, Panidis D. Adiponectin levels in women with polycystic ovary syndrome- a systematic review and a meta-analysis. Hum Reprod Update. 2009 May-Jun;15(3)297-307. doi: 10.1093/humupd/dmp006 [Crossref][PubMed] [Google Scholar]

40. Shoaib O M, Mustafa S M, Nourein I H. Serum lipid profile of polycystic ovary syndrome in Sudanese women. International Journal of Medical Science and Public Health. 2015;4(11)1605-1610. [Crossref][PubMed][Google Scholar]

41. Wild RA. Dyslipidemia in PCOS. Steroids. 2012 Mar $10 ; 77(4) 295-9$.

doi:

10.1016/j.steroids.2011.12.002 [Crossref][PubMed] [Google Scholar]
42. Weyer C, Funahashi T, Tanaka S, Hotta K, Matsuzawa $Y$, Pratley RE, Tataranni PA. Hypoadiponectinemia in obesity and type 2 diabetes- close association with insulin resistance and hyperinsulinemia. J Clin Endocrinol Metab. 2001 May;86(5)1930-5. doi: 10.1210/jcem.86.5.7463 [Crossref][PubMed][Google Scholar]

43. Tschritter O, Fritsche A, Thamer C, Haap M, Shirkavand $F$, Rahe $S$, et al. Plasma adiponectin concentrations predict insulin sensitivity of both glucose and lipid metabolism. Diabetes. 2003 Feb;52(2)239-43. doi: 10.2337/diabetes.52.2.239 [Crossref][PubMed][Google Scholar]

44. Ramanand SJ, Ghongane BB, Ramanand JB, Patwardhan $\mathrm{MH}$, Ghanghas RR, Jain SS. Clinical characteristics of polycystic ovary syndrome in Indian women. Indian J Endocrinol Metab. 2013 Jan;17(1)138-45. doi: 10.4103/2230-8210.107858 [Crossref][PubMed][Google Scholar] 